\title{
Investigation of Friction and Wear Behavior of Boron Carbide Reinforced Composite Materials
}

\author{
Banu Sugözü ${ }^{*}$, İlker Sugözü ${ }^{*}$ \\ 0000-0002-7798-2677, 0000-0001-8340-812
}

${ }^{1}$ Mersin University, Faculty of Engineering, Department of Mechanical Engineering, Mersin, Turkey

\begin{abstract}
In this study, the usability of boron carbide as a reinforcement material in friction composites was investigated experimentally. Hence, composite samples containing different amounts of boron carbide $(5 \%, 10 \%$ and $15 \%)$ were produced and compared with boron carbide-free sample. Friction and wear tests were determined by a full scale brake friction tester according to TS 555 and TS 9076 standards. The hardness of the samples was calculated by Rockwell hardness tester and the density was calculated according to Archimedes' principle. The results showed that boron carbide could be used as a reinforcement material in friction composites.
\end{abstract}

Keywords: Boron carbide, composite material, friction, wear

\section{* Corresponding author Banu Sugözü \\ banusugozu@mersin.edu.tr}

Adress: Mersin University, Faculty of Engineering, Department of Mechanical Engineering, Mersin, Turkey

Tel: +903243610001

Fax: +903243618653

Researh Article

\section{Manuscript}

Received 30.09.2019

Revised 04.11.2019

Accepted 14.11.2019

Doi: 10.30939/ijastech..627137

\section{Introduction}

Composite materials are materials formed by combining two or more materials with non-chemical methods in order to carry the desired properties according to the place where they are used. The materials that form the composites consist of matrix and reinforcement. Matrixes are materials in the form of adhesives for holding the components together. It also has the duties of holding the reinforcing materials in the desired shape and orientation, transferring the load to the fibers with reinforcing material, and protecting against external factors such as moisture and temperature. Reinforcement materials are called fiber materials which are used to increase the strength of the composite and improve its structural properties. Various materials such as glass fiber, carbon fiber, boron fiber, aramid fiber are used according to the purpose of the composite as reinforcement material in composite materials. Friction composites are used in places such as braking systems of highways and rail transport vehicles. In brake systems, kinetic energy of the vehicle is converted to heat by friction and motion is controlled. Consequently, composites that are resistant to abrasion and environmental conditions such as temperature, humidity and have high friction coefficient are preferred in brake systems. In order to meet these properties expected from composites, many components with different properties can be added to the content. In literature, it is observed that average 8-10 materials are used for friction composites [1-4].

Each material included in the content has a different purpose to form friction composites. In addition to resins used as adhesives and various fibers used as reinforcing materials, friction modifiers, solid lubricants, metallic chips for the transmission of heat caused by friction, and various fillers are used to reduce cost and increase reproducibility. In the studies [5-17], the usability of materials such as aramid fiber, carbon fiber, metal fibers, palm kernel fibers, glass fiber, fly ash fiber, sisal fiber, stone wool fiber and organic fiber as a reinforcement material was investigated experimentally. Necessary tests have been carried out using various materials such as waste vehicle dust, alumina, fly ash, banana peel, powdered pine cone and steel wool as the friction regulator [18-23]. In addition, studies on the use of boron products in friction composites [24-29] are relatively limited. 
In this study, boron carbide was used as reinforcing material in friction composites. Four samples containing $5 \%, 10 \%$ and $15 \%$ by weight of boron carbide, one of which is a reference sample without boron carbide, were produced by powder metallurgy. The wear and friction properties of the samples were obtained using a full-scale brake tester. The hardness and density measurements and the physical properties of the samples were determined and their performances were compared according to the boron carbide ratio used.

\section{Material and Method}

It has been proved by studies [21,30-36] that the type, particle size, shape and amount of the materials constituting the composite directly affect the friction and wear properties. Accordingly, the properties of the materials and the previous studies were taken into consideration while creating the composite content. Composite content and properties of materials are shown in Table 1.

Table 1. The ingredients of composites and

properties of materials

\begin{tabular}{ll}
\hline Material & Type \\
\hline Phenolic resin & Matrix (Binder) \\
Boron carbide & Reinforcement \\
Brass shavings & Metallic chips \\
Steel shavings & Solid lubricant \\
Graphite & Friction modifier \\
Powder cashew & Space filler \\
Blumina & \\
\hline
\end{tabular}

The mass amount of the composites is shown in Table 2. The mass ratio of materials other than boron carbide and barite is constant for all samples. Other materials; phenolic resin $20 \%$, brass shavings $7 \%$, steel shavings $10 \%$, graphite $3 \%$, cashew dust $10 \%$ and alumina $10 \%$.

Table 2.\% Mass content of materials in composite

\begin{tabular}{lcccc}
\hline \multirow{2}{*}{ Ingredient } & \multicolumn{4}{c}{ Mass (\%) } \\
\cline { 2 - 5 } & $\mathrm{B}_{0}$ & $\mathrm{~B}_{5}$ & $\mathrm{~B}_{10}$ & $\mathrm{~B}_{15}$ \\
\hline Boron carbide & 0 & 5 & 10 & 15 \\
Barite & 40 & 35 & 30 & 25 \\
Other components & 60 & 60 & 60 & 60 \\
\hline
\end{tabular}

B0, B5, B10 and B15 are the names given to the samples in Table 2. The letter $B$ is boron carbide and the number indicates the percentage in the composite. All the ingredients are in powder form and the conventional powder metallurgy method is used for the production of the samples. First, the powders were weighed with a precision balance and placed in a mixing bowl and mixed for 10 minutes to obtain a homogeneous mixture. The mixture was first shaped in a cold press mold and then cured with the help of hot press molds to obtain the final product. A literature review of the production conditions of the samples was performed and the parameters are shown in Table 3.

Table 3. Production parameters of composites

\begin{tabular}{|c|c|c|c|}
\hline & $\begin{array}{l}\text { Time } \\
(\min )\end{array}$ & $\begin{array}{c}\text { Pressure } \\
(\mathrm{MPa})\end{array}$ & $\begin{array}{c}\text { Temperature } \\
\left({ }^{\circ} \mathrm{C}\right)\end{array}$ \\
\hline Mixing & 10 & - & - \\
\hline Cold molding & 2 & 8 & $\begin{array}{l}\text { room tem- } \\
\text { perature }\end{array}$ \\
\hline Hot molding & 10 & 10 & 150 \\
\hline
\end{tabular}

Hardness values of the samples were calculated with Rockwell hardness tester and density measurements were calculated using Archimedes principle. Non-contact thermometer was used to measure the heat generated during friction tests and data were obtained via the friction tester software. In order to obtain the properties of the samples such as wear and friction coefficient, tests were carried out according to TS 555 (Brake Lining for Road Vehicles) and TS 9076 (Road Vehicles- Brake Linings- Evaluation of Friction Material Characteristics- Small Sample Bench Test Procedure) [37-38]. The samples were tested in a full-scale friction device shown in Fig. 1, using a gray cast iron disc of $280 \mathrm{~mm}$ diameter and $116 \mathrm{HB}$ hardness. The device is fully computer-controlled and includes data acquisition software.

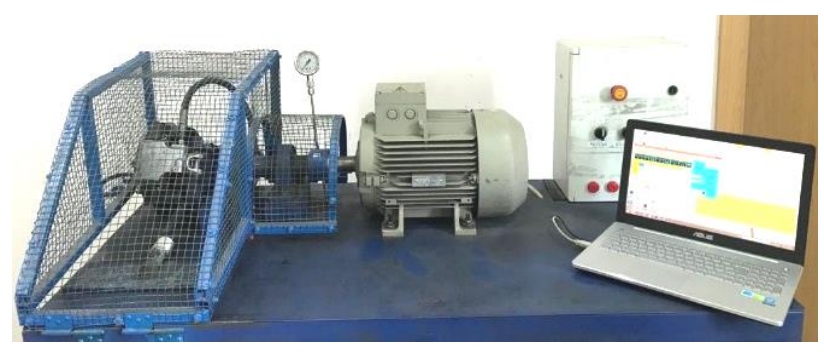

Fig. 1. Friction test equipment

\section{Results and Discussion}

The most important parameter when evaluating friction composites is the friction coefficient and specific wear rate values of the material. Composites with high friction coefficient and low specific wear rate are preferred in places such as brake systems. Graphs of change of friction coefficients depending on the friction time of the samples in seconds are shown in Fig. 2. 
$\mathrm{BO}$

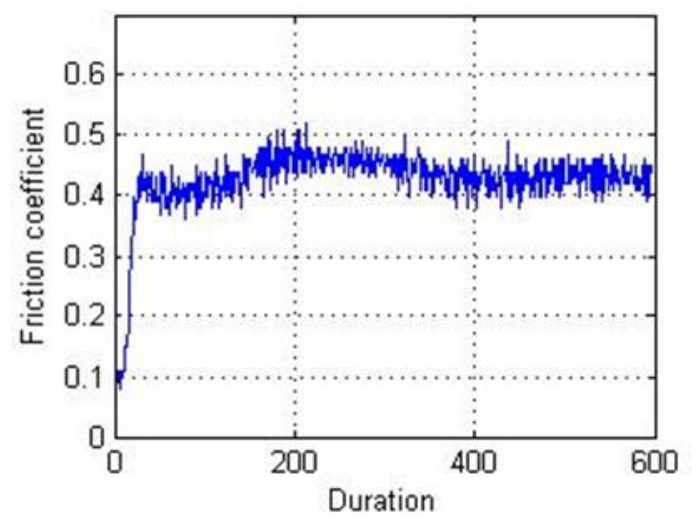

B10

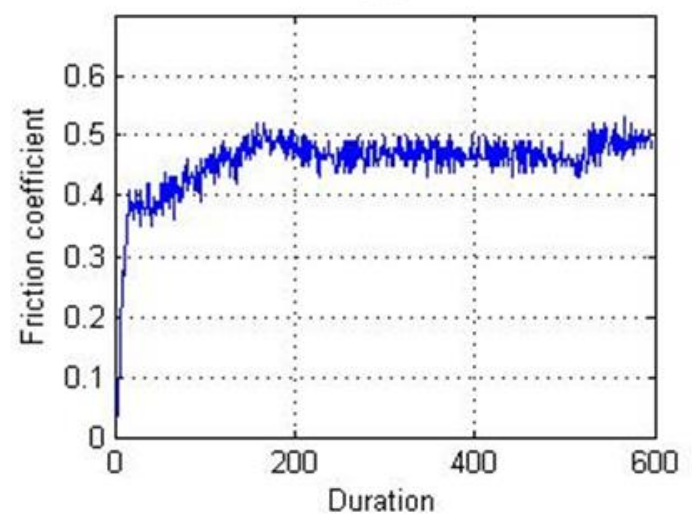

B5

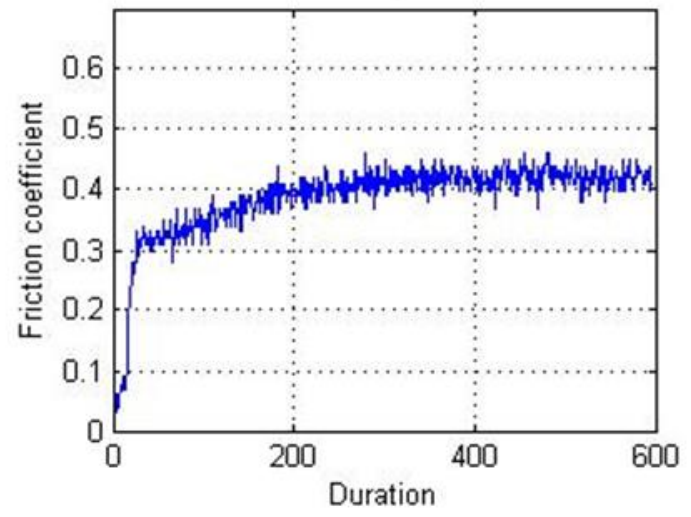

B15

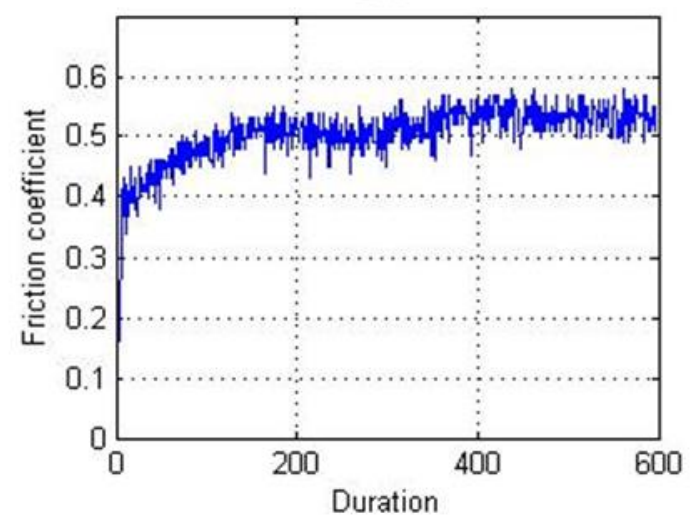

Fig. 2. The change of friction coefficient as a function of sliding time for samples

Before starting friction tests, friction was achieved until approximately $95 \%$ of the surface of the specimen and the disc contacted. This process is called "running in" in the literature. As shown in the graphs, the coefficient of friction is very low at the beginning of the test and gradually increases. This is because the pressure applied to the surface of the sample by the disc is gradually increased. Sudden pressure on the sample can cause structural damage. It can also be said that the friction force at the beginning of the test is effective because the friction layers are not yet formed. When the change in the friction coefficient depending on the amount of boron carbide is examined, it can be said that boron carbide ratio has an effect on both increasing the friction coefficient and improving the friction stability. Fig. 3 shows the temperature change between the sample and the disc during friction tests.

When examined the temperature values due to friction between the disc and the sample during friction test, it was concluded that there was no direct correlation with the boron carbide content. In addition, based on the highest temperature values, it is assumed that the contents do not harm the physical and chemical structure. If the interface temperature reaches the curing temperature of the resin that holds the materials together, the composite may be disintegrated.

The density, average friction coefficient and specific wear rate values of the samples are shown in Fig. 4. Accordingly, when the friction characteristics of the samples are examined, the average friction coefficient value of the B5 coded sample containing 5\% boron carbide is higher than the others. When the specific wear rate values are examined, it is concluded that it shows a tendency towards boron carbide amount.

When the hardness values of the samples given in Table 4 are examined, it is concluded that there is no direct correlation with the amount of boron carbide in the content. However, when the density values of the samples in Fig. 4 and hardness values are examined together, it is seen that the density increases as the hardness increases. This situation is consistent with the studies in the literature. 
$\mathrm{BO}$
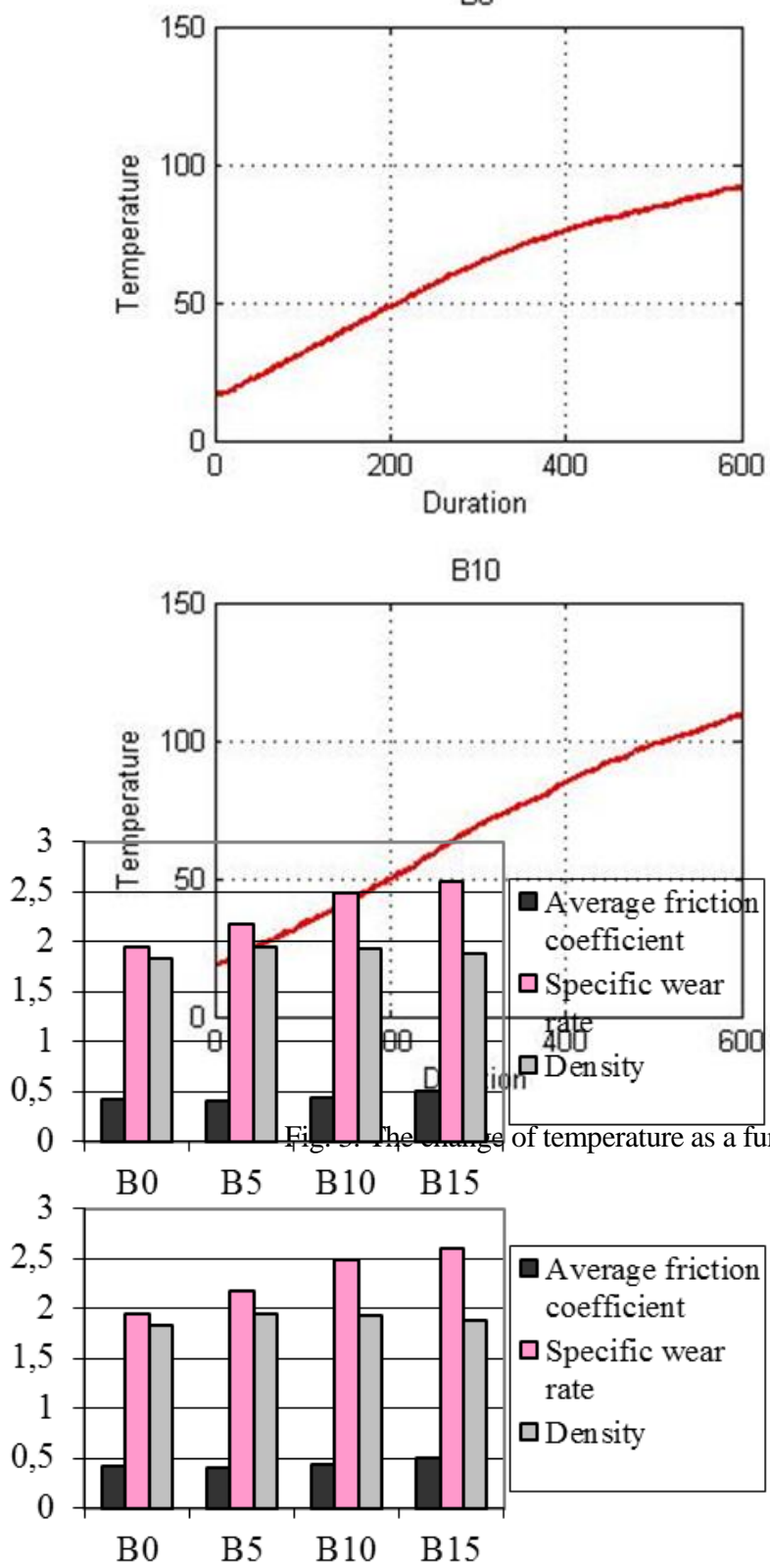

Fig. 4. Density (g/cm3), average friction coefficient and specific wear rate $(x 10-6 \mathrm{~cm} 3 / \mathrm{Nm})$ values of samples

Table 4. Rockwell hardness of composites

\begin{tabular}{cc}
\hline Sample & $\begin{array}{c}\text { Rockwell hardness } \\
(\text { HRL })\end{array}$ \\
\hline $\mathrm{B}_{0}$ & 88 \\
$\mathrm{~B}_{5}$ & 103 \\
$\mathrm{~B}_{10}$ & 99 \\
$\mathrm{~B}_{15}$ & 95 \\
\hline
\end{tabular}
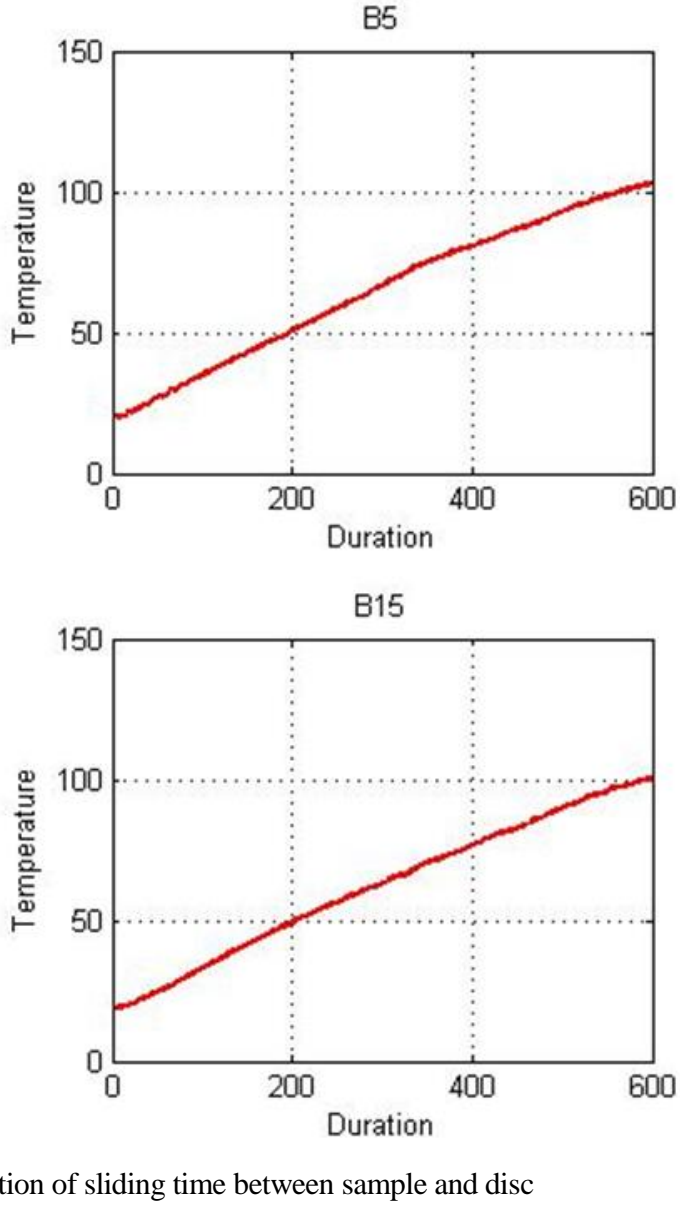

One of the parameters that should be examined when evaluating the performance of friction composites is friction stability. Friction stability is calculated as a percentage of the average friction coefficient to the highest friction coefficient reached during the test. In order for the composites to have a good friction performance, it is desirable that the friction stability be as high as possible and close to 100 . In addition, in the friction coefficient curves in Fig. 2, the slope and fluctuations are expected to be minimum. The friction stability of the samples is shown in Fig. 5.

The friction stability of the B0 coded sample without boron carbide content was $81.4 \%$, the friction stability of the B5 coded sample was $84.9 \%$, the friction stability of the B10 coded sample was $83 \%$ and friction stability of the B15 coded sample with $15 \%$ boron carbide content was calculated as $84.9 \%$.

200 magnification optical microscope images of the samples are shown in Fig. 6. As expected, abrasion gaps were found on the friction surfaces of the samples. When the distribution of metallic chips such as steel wool and brass shavings on the surface is examined, it can be said that it exhibits a homogeneous distribution. 


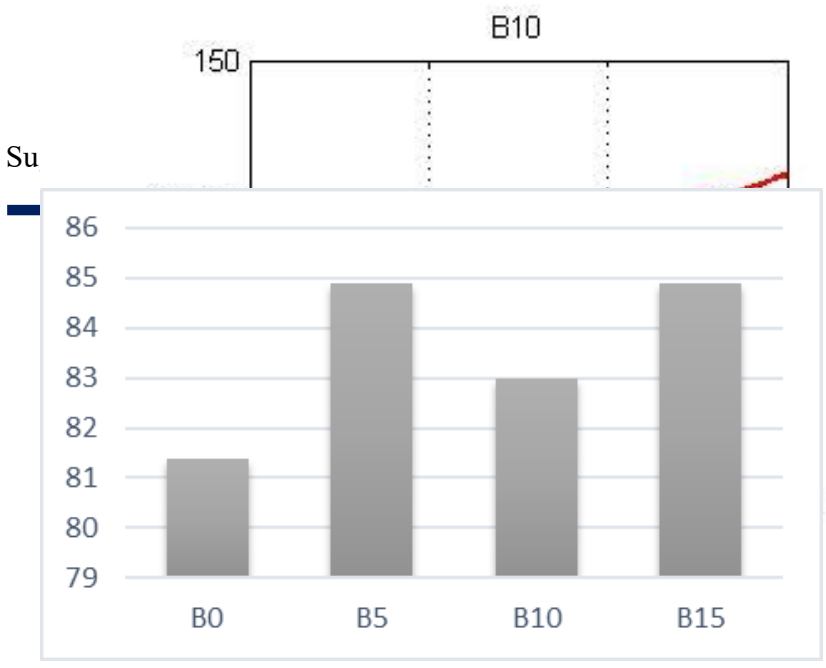

Fig. 5. Friction stability of samples (\%)

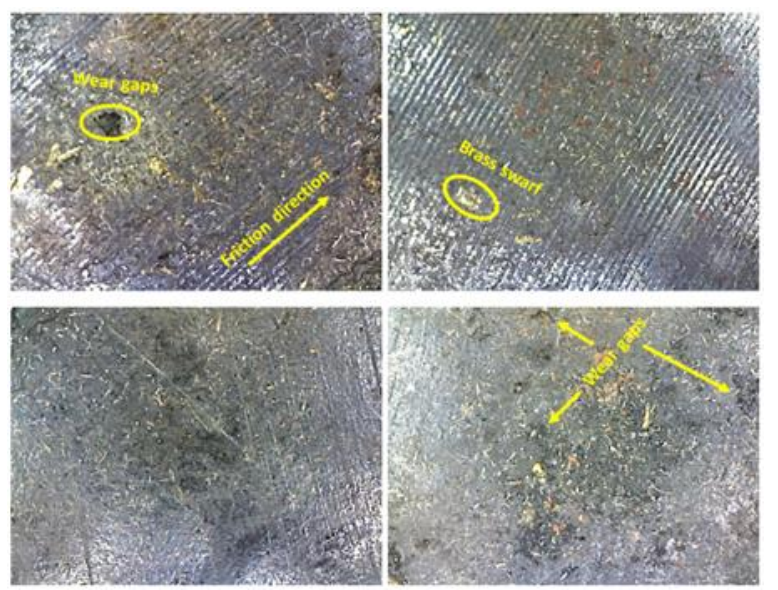

Fig. 6. Optical microscope images of samples (200 magnification)

\section{Conclusions}

In this study, the usability of boron carbide as a reinforcing material in friction composites was investigated and necessary tests were conducted. The results are summarized below:

- According to the test results, all samples are compatible with the literature, can be applied in industry and comply with TS 555 standard.

- The average friction coefficient of the B15 coded sample containing $15 \%$ boron carbide content is 0.5 and higher than the other samples.

- As the amount of boron carbide increased in samples, specific wear rate value increased. The specific wear rate also depends on the friction coefficient.

- The physical properties of the samples such as density and hardness are not directly related to the amount of boron carbide in content.

- Although the percentage of friction stability of the samples coded B5 and B15 is the same, the slope and fluctuations are less in the friction coefficient graph of the B5 coded sample.

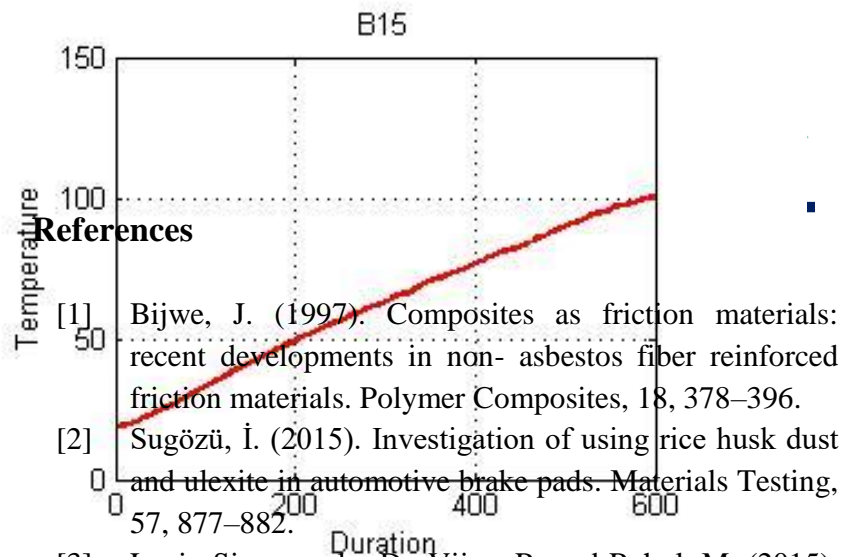

[3] Lenin Singaravelu, D., Vijay, R. and Rahul, M. (2015). Influence of Crab Shell on Tribological Characterization of Eco-Friendly Products Based Non Asbestos Brake Friction Materials. SAE Brake Colloquium \& Exhibition - 33rd Annual.

[4] Öztürk, B. and Mutlu, T. (2016). Effects of Zinc Borate and Fly Ash on the Mechanical and Tribological Characteristics of Brake Friction Materials. Tribology Transactions, 59, 622-631.

[5] Aranganathan, N., Mahale, V. and Bijwe, J. (2016). Effects of aramid fiber concentration on the friction and wear characteristics of non-asbestos organic friction composites using standardized braking tests. Wear, 354-355, 69-77.

[6] Fei, J., Li, H. J., Fu, Y. W., Qi, L. H. and Zhang, Y. L. (2010). Effect of phenolic resin content on performance of carbon fiber reinforced paper-based friction material. Wear, 269, 534-540.

[7] Dadkar, N., Tomar, B. S., Satapathy, B. K. and Patnaik, A. (2010). Performance assessment of hybrid composite friction materials based on flyash - rock fibre combination. Materials and Design, 31, 723-731.

[8] Satapathy, B. K. and Bijwe, J. (2004). Performance of friction materials based on variation in nature of organic fibres Part I. Fade and recovery behaviour. Wear, 257, 573-584.

[9] Nirmal, U., Hashim, J. and Megat Ahmad, M. M. H. (2015). A review on tribological performance of natural fibre polymeric composites. Tribology International, 83, 77-104.

[10] Jang, H., Ko, K., Kim, S. J., Basch, R. H. and Fash, J. W. (2004). The effect of metal fibers on the friction performance of automotive brake friction materials. Wear, 256, 406-414.

[11] Ikpambese, K. K., Gundu, D. T. and Tuleun, L.T. (2016). Evaluation of palm kernel fibers (PKFs ) for production of asbestos-free automotive brake pads. Journal of King Saud University - Engineering Sciences $28,110-8$.

[12] Zhang, X., Li, K. Z., Li, H. J., Fu, Y. W. and Fei, J. (2014). Tribological and mechanical properties of glass fiber reinforced paper-based composite friction material. Tribology International, 69, 156-67.

[13] Qu, X., Zhang, L., Ding, H. and Liu, G. (2004). The Effect of Steel Fiber Orientation on Frictional Properties of Asbestos-Free Friction Materials. Polymer Composites, 25, 94-101. 
[14] Öztürk, B., Arslan, F. and Öztürk, S. (2013). Effects of different kinds of fibers on mechanical and tribological properties of brake friction materials. Tribology Transactions, 56, 536-545.

[15] Ho, S. C., Chern Lin, J. H. and Ju, C. P. (2005). Effect of fiber addition on mechanical and tribological properties of a copper/phenolic-based friction material. Wear, 258, 861-869.

[16] Satapathy, B. K., Patnaik, A., Dadkar, N., Kolluri, D. K. and Tomar, B. S. (2011). Influence of vermiculite on performance of flyash-based fibre-reinforced hybrid composites as friction materials. Materials and Design, 32, 4354-4361.

[17] Xin, X., Xu, C. G. and Qing, L. F. (2007). Friction properties of sisal fibre reinforced resin brake composites. Wear, 262, 736-741.

[18] Boz, M. and Kurt, A. (2007). The effect of Al2O3 on the friction performance of automotive brake friction materials. Tribology International, 40, 1161-1169.

[19] Sugözü, B. (2018). Tribological properties of brake friction materials containing fly ash. Industrial Lubrication and Tribology, 70, 902-906.

[20] Bashir, M., Saleem, S. S. and Bashir, O. (2015). Friction and wear behavior of disc brake pad material using banana peel powder. International Journal of Research in Engineering and Technology, 4, 650-659.

[21] Sugözü, B., Dağhan, B. and Akdemir, A. (2018). Effect of the size on the friction characteristics of brake friction materials: a case study with $\mathrm{Al} 2 \mathrm{O} 3$. Industrial Lubrication and Tribology, 70, 1020-1024.

[22] Sugözü, İ. and Kahya, K. (2018). Investigation of the Effect on Tribological Properties of the use of Pinus Brutia Cone as a Binder in Brake Pads. European Mechanical Science, 2, 115-118.

[23] Bijwe, J. and Kumar, M. (2007). Optimization of steel wool contents in non-asbestos organic (NAO) friction composites for best combination of thermal conductivity and tribo-performance. Wear, 263, 1243-1248.

[24] Wannik, W. B., Ayob, A. F., Syahrullail, S., Masjuki, H. H. and Ahmad, M. F. (2012). The effect of boron friction modifier on the performance of brake pads. International Journal of Mechanical and Materials Engineering, 7, 31-35.

[25] Öztürk, B. and Mutlu, T. (2016). Effects of Zinc Borate and Fly Ash on the Mechanical and Tribological Characteristics of Brake Friction Materials. Tribology Transactions, 59, 622-631.

[26] Düzcükoğlu, H., Ekinci, Ş., Şahin, Ö. S., Avci, A., Ekrem, M. and Ünaldi, M. (2015). Enhancement of Wear and Friction Characteristics of Epoxy Resin by Multiwalled Carbon Nanotube and Boron Nitride Nanoparticles. Tribology Transactions, 58, 635-642.

[27] Akıncıoğlu, G., Öktem, H., Uygur, I. and Akıncıoğlu, S. (2018). Determination of Friction-Wear Performance and Properties of Eco-Friendly Brake Pads Reinforced with Hazelnut Shell and Boron Dusts. Arabian Journal for Science and Engineering, 43, 4727-4737.

[28] Sugozu, I., Mutlu, I. and Sugozu, B. (2018). The effect of ulexite to the tribological properties of brake lining materials. Polymer Composites, 39, 55-62.

[29] Sugözü, İ., Mutlu, İ. and Sugözü, B. (2016). The effect of colemanite on the friction performance of automotive brake friction materials. Industrial Lubrication and Tribology, 68, 92-98.

[30] Abdul Hamid, M. K., Stachowiak, G. W. and Syahrullail, S. (2013). The Effect of External Grit Particle Size on Friction Coefficients and Grit Embedment of Brake Friction Material. Procedia Engineering, 68, 7-11.

[31] Shin, M. W., Kim, Y. H. and Jang, H. (2014). Effect of the Abrasive Size on the Friction Effectiveness and Instability of Brake Friction Materials : A Case Study with Zircon. Tribology Letters, 55, 371-379.

[32] Sugözü, B., Dağhan, B., Akdemir, A. and Ataberk N. (2016). Friction and wear properties of friction materials containing nano/micro-sized $\mathrm{SiO} 2$ particles. Industrial Lubrication and Tribology, 68, 259-266.

[33] Amaren, S. G., Yawas, D. S. and Aku, S. Y. (2013). Effect of periwinkles shell particle size on the wear behavior of asbestos free brake pad. Results in Physics, 3, 109-114.

[34] Matějka, V., Lu, Y., Jiao, L., Huang, L., Simha, Martynková, G. and Tomášek, V. (2010). Effects of silicon carbide particle sizes on friction-wear properties of friction composites designed for car brake lining applications. Tribology International, 43, 144-151.

[35] Kukutschová, J., Moravec, P., Tomášek, V., Matějka, V., Smolík, J., Schwarz, J., Seidlerová, J., Šafářová, K. and Filip, P. (2011). On airborne nano/micro-sized wear particles released from low-metallic automotive brakes. Environmental Pollution, 159, 998-1006.

[36] Cho, K. H., Jang, H., Hong, Y. S., Kim, S. J., Basch, R. H. and Fash, J. W. (2008). The size effect of zircon particles on the friction characteristics of brake lining materials. Wear, 264, 291-297.

[37] TSE 555, (1992). Highway Vehicles-Brake SystemBrake Pads for Friction Brake, Ankara, Turkey.

[38] TS 9076, (1991). Road Vehicles- Brake LiningsEvaluation of Friction Material Characteristics- Small Sample Bench Test Procedure, Ankara, Turkey. 